\title{
ENFIM, POSSO FALAR!
}

Beatriz Ignatius Nogueira Carlos Roberto Vianna

\section{Introdução}

Este capítulo é síntese de uma dissertação defendida em 2019. Essa versão foi adaptada para focar somente uma das questões investigadas, mas o texto completo está disponível para acesso público no site do programa de pós-graduação (PPGECM-UFPR). Na dissertação há alternância nos discursos direto e indireto, mas aqui optamos por manter toda a narrativa na voz da primeira autora. O capítulo apresenta um problema de investigação, um pouco da história dos surdos, o percurso metodológico da pesquisa, os colaboradores e algumas reflexões sobre as entrevistas realizadas.

\section{O problema da investigação}

Sou surda e quando descobriram minha surdez os meus familiares não imaginavam que um dia eu pudesse cursar o mestrado e, muito menos, me tornar uma professora universitária, como meus pais são. Esse sentimento de que eu e minha irmã, que também é surda, teríamos dificuldades com o mundo acadêmico acontecia porque nós vivenciamos um período muito difícil na educação do surdo brasileiro. Um período em que os professores não aprendiam a se comunicar com seus alunos e mais, os próprios surdos eram proibidos de usar a Libras (Língua Brasileira de Sinais). Esse período foi muito difícil porque as pessoas acreditavam que aprender a falar oralmente era a única maneira do surdo se integrar à sociedade.

Em algum momento os sinais entraram na nossa casa, na nossa escola e, a partir daí, passamos a sonhar em fazer faculdade. Isto aconteceu porque houve uma mudança muito importante: antes, era proibido usar sinais e hoje eu sou professora de Libras! Ensino a língua dos surdos para ouvintes em uma universidade. Que mudança aconteceu?

"DOI - 10.29388/978-65-86678-60-4-0-f.15-48 
Para os estudiosos mudou a maneira de se entender a surdez, isto é, "mudou a concepção de surdez" e o surdo passou a ser considerado não mais como um "deficiente auditivo", mas como uma pessoa que se comunica de outra forma.

Agora se entende que a surdez é, como diz Skliar (1998), uma "experiência visual", o que significa que o surdo compreende as coisas usando principalmente a visão; e, se a visão é tão importante para o surdo, ela deve ser considerada como o principal canal de comunicação. Depois de muita luta e muito sofrimento, conquistamos o direito de utilizar a nossa língua, o direito de sermos educados em nossa língua.

Essa abordagem da educação dos surdos, que proibia o uso de sinais e buscando que os surdos ficassem parecidos com os ouvintes, obrigando-os a usarem aparelhos auditivos e a aprenderem a falar, é chamada de oralismo. Atualmente, a abordagem utilizada na educação de surdos é chamada de bilinguismo, essa abordagem considera que a primeira língua dos surdos é a Libras e, depois, como segunda língua, ele aprende a língua portuguesa, mas só na modalidade escrita. O surdo não é mais obrigado a aprender falar.

Quando a escola em que eu estudava aceitou usar a Libras foi uma maravilha. Tudo ficou claro! Nós começamos a entender a aula e podíamos nos comunicar com os colegas. Então, quando comecei meu mestrado, eu queria saber mais sobre como aconteceram essas mudanças. Mas, queria saber pela visão dos surdos: os instrutores de Libras que auxiliaram na transformação do oralismo para o bilinguismo e os alunos surdos que vivenciaram essa mudança. Essa foi a minha proposta de trabalho: criar fontes que permitissem enxergar essa mudança na história da educação de surdos; ajudar a compreender como mudou o pensamento das pessoas sobre a surdez, como mudaram as abordagens na educação dos surdos; e, a identificar como essa transformação aconteceu, considerando as fontes surdas. Antes de falar da pesquisa é importante contar um pouco das coisas que aconteceram, com o jeito de contar dos surdos.

\section{Um pouco de história}

Zanquetta (2006, p. 32) relata que, no Estado do Paraná, no ano de 1994, foi quando os professores começaram a estudar sobre o bilinguismo e a aprender a língua de sinais; e, para isso as escolas especializadas de surdos 
contrataram instrutores surdos. Essa mudança se concretizou em 1996 na escola em que eu estudei, e que também foi cenário da história de vida das colaboradoras desta pesquisa.

Até 1994, a escola em que minha irmã e eu estudávamos não era, pelo menos do ponto de vista legal, uma "escola". Era um Centro de Reabilitação de Menores Deficientes Auditivos e tinha, como principal objetivo, preparar as crianças para ingressarem no ensino regular comum, mediante o treinamento auditivo com o uso de próteses, a aprendizagem da leitura labial e a aquisição da língua oral. Não era ofertada a escolarização seriada.

Como, de maneira informal, neste ano de 1994 a escola contava com alunos que poderiam ser considerados da Educação Infantil e do primeiro ao terceiro ano do Ensino Fundamental, foi elaborado um projeto para a criação de uma escola de ensino regular especializada para surdos.

Tal processo foi apresentado ao Departamento de Ensino de 10 Grau da SEED-PR para apreciação, com fins de regulamentação da vida acadêmica dos alunos. Em decorrência disso, contando com o apoio e incentivo do Departamento de Educação Especial da SEED, em janeiro de 1995, através da Resolução no 195, criou-se na escola o ensino de 1응 grau. Os alunos foram submetidos a um exame classificatório com provas elaboradas de acordo com os conteúdos referentes à série anterior a que o aluno se encontrava. Uma banca, composta por professores, coordenação do Núcleo de Educação e coordenação pedagógica da escola, aplicou e corrigiu as provas; ficou, assim, regularizada a situação dos alunos (ZANQUETTA, 2006, p. 26).

A partir de 1995, agora com o nome de Colégio Modelo de Maringá, começou a oferta da segunda fase do Ensino Fundamental e, assim, foram contratados professores especialistas nas diversas disciplinas. Um grupo de profissionais da escola resolveu fazer especialização na área de deficiência auditiva e foi neste curso que a maioria tomou conhecimento da possibilidade da educação de surdos considerando a língua de sinais.

Foi muito difícil convencer as famílias a aceitarem o ensino em Libras, porque as famílias haviam sido iludidas por médicos e outros profissionais que eram oralistas, de que as crianças surdas falariam normalmente, ouvir com os aparelhos auditivos e fazer leitura labial, de maneira que seriam naturalmente integradas ao mundo ouvinte. Então, para essas famílias, adotar a Libras era como se tivessem recebido a "notícia da surdez" de seus filhos novamente. 
Algumas professoras também não aceitaram o abandono do oralismo. Algumas se aposentaram e outras voltaram a dar aulas para ouvintes.

Com os professores aprendendo Libras, com a contratação de uma instrutora surda, nós, os alunos surdos que vivenciamos esta transição, nos sentimos valorizados e, de repente, a gente estava ensinando nossos professores. A adoção da abordagem bilíngue na educação dos surdos é um avanço importante; pois, a possibilidade de estudar utilizando nossa própria língua elimina um grande obstáculo a aprendizagem. Entretanto, ainda é preciso avançar mais, por exemplo, favorecendo que os surdos aprendam o mais cedo possível a língua de sinais.

Os instrutores de Libras contratados para ensinar Libras aos professores da escola eram surdos adultos, escolarizados por meio do oralismo, que conviverem com outros surdos e aprenderam a Libras. Como essa língua era "proibida", não era ainda a Libras que hoje eu ensino para meus alunos, que é a Libras "culta", com gramática bem estabelecida. A Libras sinalizada por eles era "caseira", adquirida em contato com surdos que já sinalizavam. Como não era uma língua de uso comum eu me lembro que quando encontrávamos com surdos de outras cidades, mesmo que bem próximas, era preciso dedicar algum tempo para "combinar os sinais".

Os instrutores também ensinavam a Libras para os alunos surdos da escola, pois eles não sabiam. E por que os alunos não sabiam? Porque a escola, quando adotava o oralismo, proibia que os alunos usassem Libras. Além disso, a maioria dos estudantes eram filhos de pais ouvintes, e como a escola orientava a família a não deixar as crianças conviverem com surdos sinalizadores, elas não adquiriram sua língua. Nessa época, como a Libras ainda não havia sido reconhecida como meio de comunicação dos surdos brasileiros, não havia legislação que estabelecesse os requisitos para ser instrutor, qual o seu papel na escola etc. Isto só aconteceu com o Decreto Federal $n .5626$ de 2005.

Além de ensinar Libras para toda comunidade da escola, os instrutores também auxiliavam os professores em suas aulas e, por terem sido escolarizados no oralismo, possuíam leitura labial e oralização.

A convivência dos professores, do pessoal de apoio, da direção e, principalmente, das crianças e jovens surdos, com adultos surdos, que tinham trabalho, constituíram famílias, tinham filhos, enfim, uma vida social comum favoreceu a mudança do modo de pensar dos ouvintes sobre a surdez e dos 
próprios surdos e proporcionou modelos surdos, favorecendo a construção de nossas identidades. Esses instrutores de Libras, ensinando Libras para os professores e alunos, foram fundamentais para que acontecesse a mudança para o bilinguismo. Mas, como foi para eles serem protagonistas dessa transição?

E, como foi para os alunos surdos, que antes eram proibidos de conviver com surdos, proibidos de sinalizar, ver, de repente, adultos surdos sinalizadores ensinando Libras para seus professores e para eles mesmos? Será que eles tiveram consciência dessa libertação?

Um dos objetivos da pesquisa foi o de criar fontes surdas, fontes que registram os relatos dessas pessoas e permitem ajudar a compreender como aconteceu a mudança do oralismo para o bilinguismo nas escolas para surdos.

Essa transformação da abordagem educacional não aconteceu de repente. A mudança acontece quando as pessoas mudam seu pensamento, mudam o que acreditam, e isso demora para acontecer. As pessoas ficam com dúvidas quando precisam abandonar a maneira como pensam. É essa mudança que minha investigação pode ajudar a entender melhor.

Desde o início da história da educação de surdos, a grande questão era se esse ensino deveria ser focado só na fala, ou se poderia também usar os gestos. A decisão sobre qual método usar sempre foi dos ouvintes, e como para eles ouvir e falar é fundamental, os ouvintes sempre escolheram o oralismo como maneira de educar os surdos. Então, durante muito tempo, os surdos precisaram aprender a falar.

Mas, como está a educação de surdos nesse século XXI?

Para mudar o pensamento sobre a importância da palavra oral, foram necessários muitos estudos para comprovar que as línguas de sinais constituem uma língua, do ponto de vista linguístico e que desempenham no desenvolvimento afetivo, cognitivo, emocional e social dos surdos, as mesmas funções desempenhadas pelas línguas orais no desenvolvimento dos ouvintes.

Outra coisa que precisou mudar foi o que as pessoas pensam que é a surdez. De doença, de deficiência, de anormalidade (como pensavam aqueles que acreditavam no oralismo), a ideia que se tem sobre a surdez mudou para a surdez entendida como uma diferença linguística, como pensam os que acreditam no bilinguismo. Mas essa transformação não aconteceu de repente; o movimento de mudança se dá pela transformação do pensamento, e isso demora. 
Essa mudança provocou uma profunda alteração na educação de surdos e é legítimo perguntar se ao deixar de se preocupar com o ensino da língua oral, da leitura labial e com os infindáveis treinamentos auditivos, o foco da atenção dos professores poderia, finalmente, se dirigir aos conteúdos das disciplinas escolares.

No passado tentaram transformar os professores que trabalhavam com alunos surdos em uma espécie de "terapeuta" com capacitação sobre diferentes métodos oralistas, tentando ensinar o surdo a falar, a fazer leitura labial com exaustivos treinamentos para aproveitar as próteses auditivas dos seus alunos. Os alunos surdos, transformados em "pacientes", eram "[...] vistos como deficientes e proibidos de utilizar sinais para se comunicar; na escola, eram poupados dos conteúdos escolares mais complexos e, quando matriculados no ensino regular, eram empurrados de uma série para outra" (ZANQUETTA, 2006, p. 19). Eu grifei a palavra "poupados" no texto, porque, na minha opinião, nós não éramos "poupados", mas, sim, privados dos conteúdos escolares. Nós ficávamos tanto tempo "aprendendo falar" que não dava tempo de estudar outras coisas. O fato dos surdos aprenderem "menos conteúdos" era naturalizado pelos docentes, pois, durante "[...] muitos anos, os professores estabeleceram, de forma absurda, objetivos de baixo nível para as crianças surdas, não lhes possibilitando por isso grandes expectativas escolares e profissionais" (GOMES, 2010, p. 29).

Como eu sou trigêmea e nosso irmão não é surdo, minha irmã e eu víamos os livros e cadernos dele e tínhamos consciência do quanto nossa educação estava atrasada em relação a dele. Lembro que eu ficava olhando fascinada para os livros que ele usava na escola e nós só tínhamos cópias em cadernos ou folhas mimeografadas pelos professores das classes especiais. Em nossa sala de aula, os alunos eram de faixa etária diferente e possuíam conhecimentos diferentes. Em uma mesma folha de atividades mimeografada pela professora, havia conteúdos para atender a todos os alunos, então a professora falava quais atividades era para a gente fazer. Outro momento difícil era quando minha mãe encapava os cadernos de todos nós, os cinco. Nos cadernos dos meus irmãos ela colava uma etiqueta com o nome deles e o ano (naquela época era série) que eles estudavam. Minha irmã e eu tínhamos bem menos cadernos do que eles, e não tinha na etiqueta qual era o ano que a gente estudava. De maneira geral, a educação dos surdos era feita em classes especiais. Apenas grandes centros, como algumas capitais, mantinham escolas 
especializadas para surdos, mas a maioria delas não oferecia escolarização regular.

Os avanços nas pesquisas sobre as línguas de sinais recomendam que a criança surda tenha acesso o mais cedo possível à língua de sinais e que, posteriormente, aprenda a língua de seu país, se necessário, apenas na modalidade escrita, a partir de uma perspectiva do bilinguismo. Entretanto, para que os surdos brasileiros pudessem ter direito a uma educação bilíngue, muitas lutas aconteceram.

A Libras só foi reconhecida como a língua dos surdos brasileiros em 2002, mas durante a década de 1990, em muitos Estados, como o Estado do Paraná, já acontecia um processo de reconhecimento. Vários eventos realizados no Brasil durante esta década de 1990 discutiram a proposta bilíngue.

Em 1999, durante a preparação do $V$ Congresso Latino Americano de Educação Bilíngue para surdos (realizado na Universidade Federal do Rio Grande do Sul, em Porto Alegre, de 20 a 24 de abril de 1999) a comunidade surda elaborou um documento intitulado $A$ Educação que nós surdos queremos, tratando do "[...] estabelecimento de propostas pedagógicas, princípios educativos, estrutura escolar, formação de profissionais etc." (CUNHA JÚNIOR, 2015, p. 185).

No Decreto 5.296/2004, promulgado após a Lei da Libras, as pessoas surdas voltaram a ser denominadas de deficientes auditivas e a ter sua caracterização estabelecida pelo modelo médico, com classificação decorrente do grau da perda auditiva. O fato de se ter um recuo na forma como denominar as pessoas surdas mostra que a história tem muitas idas e vindas, avanços e retrocessos.

Dentre as ações desencadeadas pelo Decreto Federal n. 5.626/2005, que institui sobre a Lei de Libras, em 2006 teve início o curso de Licenciatura em Letras/Libras, com nove polos, coordenados pela Universidade Federal de Santa Catarina (UFSC), cujas vagas foram destinadas, prioritariamente, a estudantes surdos. Em 2010 forma-se, em Florianópolis, na UFSC, a primeira turma de Licenciados em Letras/ Libras, composta exclusivamente por surdos, e eu fiz parte dessa turma. No ano seguinte minha irmã se formou pelo polo da Universidade Federal da Grande Dourados em Mato Grosso do Sul.

Antes de ingressarmos no Curso de Licenciatura Letras/Libras, minha irmã e eu já tínhamos concluído cursos de graduação (ela em Gastronomia e 
eu em Artes Visuais). Nossas graduações foram realizadas em uma universidade privada, sem a presença de intérpretes. Primeiro, tentamos que a instituição contratasse ou que nos ajudasse com bolsa de estudos, mas não conseguimos; então, a nossa família contratou os intérpretes com recursos próprios.

Este relato é importante, porque quero destacar como o curso de Letras/Libras realizado totalmente em Libras, com professores surdos ou fluentes em Libras, com colegas surdos, com intérpretes disponíveis, com material didático que destacavam o aspecto visual foi importante para nós. Parecia que estavamos em um "mundo surdo". Pela primeira vez estávamos estudando sem precisar do auxílio de um ouvinte. Não precisávamos de ajuda para nada. Entendíamos as aulas, sabíamos quais eram as nossas obrigações, ninguém precisava nos avisar das datas de provas e trabalhos. Foi um período em que nos sentimos valorizadas e autônomas. Conversávamos muito sobre isso e principalmente percebemos que, nesse curso, a gente não necessitava do apoio de nossa mãe, como em outros momentos de nossa escolarização. Não era por causa dela que a gente estava tendo um bom desempenho. No curso de Letras/Libras, os nossos colegas surdos que não contavam com apoio como nós tínhamos, também seguiam adiante. E nossa mãe, foi dispensada! Cada fato, cada pedaço da história da educação dos surdos no Brasil me traz lembranças, porque eu faço parte desta história.

A Lei da Libras foi um marco na nossa história. Não apenas pelo seu objeto, de reconhecer como legítima a forma de comunicação, mas pelo que veio depois dela. O curso de Licenciatura em Letras/Libras, a obrigatoriedade de intérprete durante toda a escolarização dos surdos, inclusive na pósgraduação; a oportunidade de trabalharmos como professores de cursos superiores; as pesquisas sobre nossa língua; o surgimento de revistas que apresentam trabalhos acadêmicos videogravados. Tudo isso criou um mundo novo para nós.

Para que se veja a diferença do nosso mundo em épocas diferentes basta comparar a Lei 3.071/1916, que considera os surdos incapazes por "não poderem exprimir a sua vontade", com a Lei 13.146/2015 que diz que o poder público deve estimular e apoiar a adaptação e a produção de artigos científicos em formato acessível, inclusive em Libras. Isso mostra a mudança, do ponto de vista das leis, no modo de entender o que é o surdo e a surdez, no período de um século. O surdo passou de ser considerado incapaz, em 1916, para alguém 
com condições de seguir carreira acadêmica, produzir e consumir artigos científicos.

Esse estudo da história que vivemos e das mudanças na legislação nos dá uma ideia sobre como as coisas aconteceram, mas para compreender como as pessoas alteraram o seu modo de pensar sobre a surdez, e para deixar o registro de como viveram e sentiram essas mudanças, é que procurei os surdos e perguntei a eles o que tinham a dizer sobre isso.

\section{Percursos metodológicos}

Para responder a minha questão da pesquisa entrevistei instrutores surdos de Libras e alunos surdos que vivenciaram a transformação do período oralista para o período do bilinguismo nas escolas. Essas entrevistas podem ser usadas como fontes para novas pesquisas e elas são importantes por darem ao público o registro do que surdos disseram que aconteceu.

A minha dissertação estava prevista para ser feita apenas em Libras, mas como o surdo também precisa saber a língua portuguesa na modalidade escrita, decidimos (meu orientador e eu) apresentar este trabalho em duas formas: a Libras e a tradução para a língua portuguesa, seguida de uma retextualização dos meus escritos, com auxílio de pessoas ouvintes. Na retextualização é feita uma construção do texto com a escrita da língua portuguesa culta, mas tentando não perder os traços próprios da escrita surda original. Esta maneira de escrever foi a saída que encontramos para tentar fazer com que a dissertação escrita preservasse a expressão do meu pensamento.

Todo trabalho de pesquisa passa por mudanças. Algumas, segundo meu orientador, é normal mudar, mas outras aconteceram por causa da minha diferença linguística. A minha língua é diferente da língua em que estou apresentando este trabalho. Por isso é que conto as mudanças da minha pesquisa, penso que isso pode ajudar a resolver dúvidas de outros pesquisadores surdos.

O que eu sempre quis entender foi como aconteceu a transição do oralismo para o bilinguismo na escola de surdos. Primeiro, eu pensei que para entender essa mudança eu deveria construir as narrativas de professores ouvintes que defendiam o oralismo e depois passaram a defender o bilinguismo. Eu já havia identificado professoras ouvintes, fluentes em Libras, 
que vivenciaram essa mudança. Mas nas conversas com meu orientador achamos melhor procurar as pessoas surdas para saber como elas viveram essas mudanças. Para registrar o que essas pessoas tinham a dizer. Para me preparar para as entrevistas fiz um levantamento bibliográfico com o objetivo de encontrar trabalhos que tiveram colaboradores surdos.

Rios e Silveira (2016, p. 292) apresentam um questionamento para quando se pretende fazer uma investigação usando História Oral com colaboradores surdos: "[...] como uma proposta de História Oral poderia estar associada com sujeitos surdos, ou seja, que não usam uma língua oralauditiva?". Mas, os pesquisadores Rios e Silveira (2016) são ouvintes e sou surda. Quando cursei a disciplina História Oral, já no início, com os procedimentos realizados pelos meus colegas, que audiogravavam as entrevistas para transcrever depois, fiquei pensando: o que é o som? Com as discussões que eu observava e tentava entender, com o auxílio dos intérpretes, eu via associarem símbolos às falas dos entrevistados: "Aqui teve hesitação", "Aqui havia uma dúvida"... "Parece pensar"! Como as pessoas ouvintes podem compreender as emoções de quem está contando alguma coisa, se tem dúvida, se está fazendo piada, se está bravo, somente pelo som? Para mim, é muito mais fácil, eu pensava, porque estou VENDO as expressões do surdo.

Para poder conseguir as histórias dos surdos, eu, que também sou surda, o certo seria videogravar. E, como ficaria no meu caso? Embora conhecêssemos as normas da Federação Nacional de Educação e Integração dos Surdos (FENEIS) para a transcrição da Libras para a língua portuguesa, optamos por adaptar as normas estabelecidas por Preti $(1999$, p. 11), já considerando a tradução para a língua portuguesa, mas respeitando a sintaxe da Libras (Quadro 1). Então, elaboramos um Quadro, adaptado para a transcrição de um vídeo em Libras, já se considerando a tradução para a Língua Portuguesa e algumas observações extraídas do Sistema de Transcrição da FENEIS.

Quadro 1: NORMAS PARA TRANSCRIÇÃO LIBRAS / LÍNGUA PORTUGUESA

\begin{tabular}{ccl}
\hline OCORRÊNCIAS & SINAIS & \multicolumn{1}{c}{ Ocorrências em Libras } \\
\hline $\begin{array}{c}\text { Incompreensão de } \\
\text { sinais ou segmentos }\end{array}$ & ( ) & $\begin{array}{l}\text { O vídeo pode estar ruim } \\
\text { O sinal não foi compreendido } \\
\text { Pode ser apenas mímica ou sinal com } \\
\text { variação linguística }\end{array}$ \\
\hline Hipótese do que & (hipótese) & Alguma coisa não ficou clara, mas o contexto \\
\hline
\end{tabular}




\begin{tabular}{|c|c|c|}
\hline ouviu & & $\begin{array}{l}\text { permite ter uma ideia do que se falou. Às } \\
\text { vezes pode faltar um verbo. Nunca vai } \\
\text { acontecer de faltar pronomes, porque a } \\
\text { Libras utiliza apontamentos para mudança de } \\
\text { referências }\end{array}$ \\
\hline Truncamento & / & $\begin{array}{l}\text { Pode acontecer do sinalizador interromper o } \\
\text { movimento de um sinal ao mesmo tempo em } \\
\text { que expressa alguma emoção pela expressão } \\
\text { facial, como dúvida, assombro, etc..., e depois } \\
\text { continua sinalizando. }\end{array}$ \\
\hline $\begin{array}{l}\text { ENTONAÇÃO } \\
\text { ENFÁTICA }\end{array}$ & maiúscula & $\begin{array}{l}\text { No caso da Libras, a modulação de sinais, que } \\
\text { é o equivalente à entonação e prosódia na } \\
\text { Língua Portuguesa, é realizada pelas } \\
\text { expressões faciais. }\end{array}$ \\
\hline $\begin{array}{l}\text { Prolongamento de } \\
\text { vogal e consoante } \\
\text { como s ou r }\end{array}$ & $\begin{array}{c}\text { :: podendo } \\
\text { aumentar para :::: } \\
\text { ou mais }\end{array}$ & $\begin{array}{l}\text { Pode acontecer o que em Libras se } \\
\text { caracteriza por Flexão de Aspecto. Alteração } \\
\text { no movimento do sinal, acompanhada de } \\
\text { expressão facial, como o inflar das bochechas } \\
\text { para representar o que se expressa } \\
\text { oralmente por MUUUUUIIITO, ao mesmo } \\
\text { tempo em que se repete o movimento. }\end{array}$ \\
\hline Silabação & - & $\begin{array}{l}\text { Não é possível realizar um parâmetro de cada } \\
\text { vez. Mas pode haver uma separação de sinais } \\
\text { compostos, como se estivesse sinalizando } \\
\text { devagar. Por exemplo, o sinal para escola: } \\
\text { casa^estudar, que é realizado quase que } \\
\text { simultaneamente, ser realizado com espaço } \\
\text { de tempo entre o sinal para casa e o de } \\
\text { estudar. } \\
\text { Da mesma forma que na silabação, a função } \\
\text { aqui é destacar o que está sendo sinalizado }\end{array}$ \\
\hline Interrogação & $?$ & $\begin{array}{l}\text { Os diferentes pronomes interrogativos são } \\
\text { expressos por diferentes sinais (muda } \\
\text { particularmente a expressão facial), ou seja, } \\
\text { os sinais para Como? O que? Quando? Por } \\
\text { que? Não são os mesmos. Além disso, os } \\
\text { pronomes interrogativos vêm sempre no final } \\
\text { da frase. }\end{array}$ \\
\hline Qualquer pausa & $\ldots$ & Situação similar \\
\hline $\begin{array}{l}\text { Comentários } \\
\text { descritivos do } \\
\text { transcritor }\end{array}$ & ((minúscula)) & ((passou a mão nos cabelos)) \\
\hline $\begin{array}{l}\text { Comentários que } \\
\text { quebram a } \\
\text { sequência temática }\end{array}$ & $\ldots$. & Análogo à Língua Portuguesa \\
\hline
\end{tabular}




\begin{tabular}{|c|c|c|}
\hline $\begin{array}{c}\text { da exposição; } \\
\text { desvios temáticos }\end{array}$ & & \\
\hline $\begin{array}{c}\text { Superposição, } \\
\text { simultaneidade de } \\
\text { vozes }\end{array}$ & & $\begin{array}{l}\text { Não há ocorrência de superposição de sinais. } \\
\text { Em Libras é possível conversas cruzadas sem } \\
\text { comprometimento da compreensão }\end{array}$ \\
\hline $\begin{array}{l}\text { Indicação de que a } \\
\text { fala foi tomada ou } \\
\text { interrompida em } \\
\text { determinado ponto. } \\
\text { Não no seu início, } \\
\text { por exemplo. }\end{array}$ & {$[\ldots]$} & Análogo à Língua Portuguesa \\
\hline $\begin{array}{l}\text { Citações literais ou } \\
\text { leituras de textos } \\
\text { durante a gravação }\end{array}$ & " “ & Análogo à Língua Portuguesa \\
\hline
\end{tabular}

Fonte: A dissertação da autora

\section{OBSERVAÇÕES (Adaptação e acréscimos a Preti (1999, p. 11):}

1. Iniciais maiúsculas: só para nomes próprios ou para siglas (USP etc.)

2. Fáticos: ah, éh, ahn, ehn, uhn, tá (não por está: tá? você está brava?)/

Em Libras existem situações análogas a tá/está; mas fáticos como ah, éh, ahn; ehn, unh, que indicam hesitações, dúvidas, exclamações ou concordância são possíveis de serem captados pelas expressões faciais ou demais componentes não manuais. Uma pausa com o olhar para o alto, pode indicar uma hesitação, por exemplo.

3. Nomes de obras ou nomes comuns estrangeiros são grifados.

4. Números: por extenso.

5. Não se indica o ponto de exclamação (frase exclamativa)

6. Não se anota o cadenciamento da frase.

7. Podem-se combinar sinais. Por exemplo: oh:::....(alongamento e pausa).

8. Não se utilizam sinais de pausa, típicos da língua escrita, como ponto-e vírgula, ponto final, dois pontos, vírgula. As reticências marcam qualquer tipo de pausa.

9. Na Libras não há desinências para gênero, número ou pessoa, entretanto, essas características podem ser depreendidas do contexto, de maneira que podemos utilizar o símbolo @, quando o contexto não for explícito ou estabelecer uma hipótese.

10. A indicação do que foi soletrado, deve ser respeitada, pois pode trazer informações adicionais, como, por exemplo o desconhecimento do entrevistado sobre o sinal ou mesmo a inexistência deste sinal. 
Por fim, cada entrevista feita em Libras foi transcrita e retextualizada. No texto final, meus comentários aparecem entre parênteses e em itálico. $\mathrm{Na}$ dissertação cada narrativa ocupa um capítulo cujo título é o nome do colaborador da pesquisa. Neste texto essas narrativas não serão apresentadas. Meu trabalho contém narrativas surdas, são narrativas feitas para uma pesquisadora que também é surda. A existência de laços afetivos dos colaboradores comigo favoreceu que eles se sentissem à vontade, conforme Souza et al (2000) apontam em seu texto:

Os surdos nas associações se colocam na escuta uns dos outros, para "ouvirem" suas histórias e anseios, momentos em que o passado se torna presente e o futuro passa a ser tecido a muitas mãos, a partir de muitos teares que carregam marcas históricas e singulares [...] Em situações espontâneas, sinalizando com o outro, o surdo reflete, revisa e retoma a sua própria história, atribuindo relevância ao narrar na medida em que é a escuta do outro que a legitima como história (SOUZA et al, 2000, p. 6).

Mais do que isso, como eu também fiz parte dos acontecimentos que eles relatavam, a entrevista se transformou em uma espécie de conversa:

A narração e a conversação são os gêneros orais mais fundamentais para qualquer sociedade humana. Não há nenhuma sociedade em que as pessoas não usem a língua para conversar e para contar histórias: seja nas interações linguísticas mais corriqueiras ou naquelas que fazem parte de grandes empreendimentos, nós estamos sempre conversando uns com os outros e, durante as conversas, quase sempre contamos histórias (SILVA, 2014, p. 1).

Para conduzir a entrevista optei por um questionário semidireto com um roteiro prévio, mas sempre procurando deixar os entrevistados livres. As perguntas só foram utilizadas quando os colaboradores ficavam "sem assunto" ou quando "fugiam" muito do tema. Para mim a entrevista seria como uma "contação de histórias em situação face a face":

A contação de histórias em situação face a face é um dos tipos de atividades linguística mais comuns que realizamos. Desde enunciados simples usados na descrição de eventos cotidianos triviais (e.g. eu vi você ontem) até histórias extensas e elaboradas que requerem um turno de 
fala mais estendido, narrativas estão em praticamente todas nossas interações comunicativas. (SILVA, 2014, p. 10)

No decorrer da investigação senti necessidade de contar a minha história, até mesmo porque, durante as entrevistas com os colaboradores eles se dirigiam a mim e quase que pediam a minha confirmação para seus relatos, com comentários do tipo: "Você lembra?"

A necessidade de narrar é ontológica. Desde os tempos mais remotos, as dimensões do vivido, sentido e realizado são contadas entre os homens. A noção de perpetuação, continuidade, herança está visceralmente arraigada aos fatos narrados e lembrados. A estruturação de narrativas é, portanto, uma condição humana que redimensiona as relações com a natureza e a cultura. Por meio delas, a coletividade, o outro e a história são acessados. Marcas e pistas são deixadas nas palavras, que traduzem tradições. Crenças, valores e possibilidades de existir se fazem presentes, atuantes no e pelo discurso (SILVA; ABREU, 2014, p. 385).

As minhas questões para os colaboradores estavam organizadas em três "blocos". O primeiro bloco, composto de quatro questões, foi destinado à apresentação do colaborador e as suas recordações da escola, de forma geral. O segundo bloco, composto de seis questões, procurou identificar como o colaborador vivenciou a transformação do oralismo para o bilinguismo. E o terceiro bloco, composto de cinco questões, procurou identificar as mudanças ocorridas nas aulas de Matemática. Tudo isso está detalhado na versão completa da dissertação.

Como já afirmei, para me preparar para as entrevistas tive que ler muito. Fazer esses estudos, ler os textos sobre narrativas, sobre História Oral, enfim, toda a parte teórica foi muito difícil para mim, porque eu precisava ler e "traduzir" para Libras o que estava lendo, para poder entender. Isto exigiu uma retextualização, da Língua Portuguesa para Libras. Porque mesmo para fazer um fichamento do que eu estava lendo, eu lia em português, pensava em Libras e tentava resumir em Libras, então estava usando um texto de uma língua oral/escrita e reelaborando em uma língua de outra modalidade, ou seja, visual/espacial. Desta forma, na "tradução" somente para compreender o que eu lia, o texto escrito já mudava, porque eu precisava interpretar o que eu estava lendo e encontrar sinais equivalentes para reproduzir o que eu lia. 
O processo de retextualização é, portanto, entendido como decorrendo explicitamente de informações que vêm de um texto específico oral ou escrito, que serve como fonte de informações, mas essas informações são, sobretudo transformadas no texto retextualizado (BARBOSA; SOUZA, 2018, p. 500).

De acordo com Barbosa e Souza (2018, p. 495), "[...] o sentido do texto em português é mais preservado no texto em Libras quando o sujeito conhece bem as duas línguas envolvidas". Eu sempre achei que conhecia bem português porque sempre gostei muito de ler. Mas as coisas que eu lia eram simples, como gibis e revistas. Quando fiz minha Licenciatura em Artes, tinha uma intérprete que me ajudava e na Licenciatura em Letras/Libras, todo material era produzido também na língua de sinais. Foi muito difícil compreender textos científicos. Mesmo a parte da história da educação de surdos que eu gostei de ler, tinha palavras difíceis que eu precisava usar dicionário ou pedir ajuda da minha mãe, porque faltavam sinais para as palavras. Quando fui fazer a transcrição das entrevistas da Libras para a língua portuguesa também ficaram buracos porque faltaram palavras para mim.

Outro problema que pode acontecer quando é feita uma retextualização da língua portuguesa é nós surdos "inventarmos" coisas para completar os buracos. Barbosa e Souza (2018) encontrou em sua investigação uma estratégia de retextualização denominada de acréscimo, que é quando quem está fazendo retextualização coloca informações que não existiam no texto original, as que ele "infere" da leitura feita.

No início do processo de elaboração desta redação, nós pensamos, meu orientador e eu, que a minha dissertação seria toda em Libras e meu orientador iria se basear na "textualização diferida" para justificar esta opção para a coordenação do meu programa de pós-graduação, baseado, principalmente no artigo do uruguaio Leonardo Peluso, publicado na revista Cadernos Traduções da UFSC em 2015.

Para Peluso (2015) os registros em vídeo de depoimentos em línguas de sinais também são fontes de informação, porque podem ser arquivados e tem as mesmas características dos textos escritos. Ele demonstra que o que está vídeogravado em língua de sinais tem mesmo valor como fonte de informações de um texto escrito e podem ser considerados "documentos". Isto porque são registros que podem ser arquivados; também possuem a "condição de permanência", isto é, não mudam, da mesma forma que os 
textos escritos e, por fim, também como os textos escritos, os vídeos possuem "objetivação", o que quer dizer que podem ser estudados, usados depois que foram feitos.

E nesse artigo o autor explica a razão da maior dificuldade que encontrei nesse trabalho, que é a transcrição da Libras para o português. Parece que faltam palavras porque a Libras, por causa do visual, percebe mais emoção, parece que tudo é mais verdadeiro. Quando se escreve em português, parece que não é igual ao que foi falado em Libras. Para Peluso (2015), a escrita representa o que foi falado e o que está gravado registra a língua. No texto fica registrado a fala, nas gravações fica registrado quem está falando e aparecem suas expressões. Quando você está fazendo transcrição de conversa falada, então até é possível registrar as emoções, porque é de palavra para palavra, então dá para escrever que a pessoa fez pausa ou deu risada... De sinal para palavra, como a expressão facial é parâmetro da Libras, então faz parte do sinal, é mais difícil.

Peluso (2015) diz também que é preciso criar materiais para os surdos poderem estudar na língua deles. Ele diz que a tentativa de se produzir coisas escritas no SignWriting não deu muito certo, porque este sistema ainda está pouco difundido e argumenta que o melhor é criar produções em língua de sinais em vídeo. Mas, o mais importante é que com as tecnologias atuais, as gravações podem ser conhecidas dos surdos. Então, penso que uma contribuição do meu trabalho para a comunidade surda é também deixá-lo todo em Libras, disponível no Youtube, por exemplo.

Com este pensamento, meu orientador indicou que eu procurasse conhecer como é possível videogravar textos científicos e me indicou a Revista Brasileira de Vídeo Registros em Libras, da Universidade Federal de Santa Catarina, que é um periódico especializado em língua de sinais e publica artigos científicos em Libras. Para isso, a revista criou regras, normas para os vídeos acadêmicos em Libras e que acompanham as normas de quase todos periódicos escritos.

O site é http://revistabrasileiravrlibras.paginas.ufsc.br/, mas, quando fui consultar, só tinha três números publicados e a última publicação foi em 2017. Que pena!

Fui então estudar as normas da revista e, dentre elas, destaco que orienta que é preciso um fundo branco, sem mancha, sem objeto, com luz suave. Relata que não pode usar brincos, usar roupa neutra e sem sombras. $\mathrm{O}$ 
resumo deve ter duração entre $1 \mathrm{~h} 30$ a $3 \mathrm{~h}$, sinalizando normal. Não precisa ser devagar. Para gravar o resumo, se a pele é branca é preciso usar roupa azul escuro e se a pele for escura, a roupa deve ser bege para o título. Para o resto do texto do resumo as cores são preto (pele clara) ou cinza (pele escura). As blusas precisam ser de manga comprida. As palavras-chave são na mesma cor do texto. São muitas exigências. As citações também têm regras e muda cor da camiseta. Então, a conclusão foi que para fazer a dissertação inteira assim, seria preciso ter acesso a um estúdio de gravação e a profissionais para fazer edição e eu não teria como fazer. Então, decidi que ia escrever a dissertação, porque na Lei 10. 436 de 2002, a Lei da Libras, está claro que a Libras não substitui a modalidade escrita da língua portuguesa.

Mas, tem também um ponto muito importante: se eu quero "dar voz" ao surdo, essa voz precisa ser "ouvida" pelos ouvintes. Não adianta só falar entre nós. Os ouvintes precisam conhecer o que os surdos pensam, o que sentiram. Então, a decisão final foi: fazer a dissertação escrita, nas normas da UFPR e realizar vídeos simples, na minha casa mesmo, de cada parte da dissertação, para acesso dos surdos.

\section{Os colaboradores da pesquisa}

Já no início do trabalho foi necessário estabelecer critérios para escolher os colaboradores que seriam entrevistados. Escolhi primeiro quatro pessoas surdas, todas com curso superior, das quais duas atuam como docentes de Libras em universidades públicas paranaenses, a saber: Valéria Cristina Camparoto de Souza; Viviane Romero Girotto; Kênia Jéssica Yamanaka Gôngora e Marília Ignatius Nogueira Carneiro (minha irmã). Valéria e Viviane, na segunda metade da década de 1990, foram as primeiras instrutoras de Libras de uma escola especializada para surdos. Kênia e Marília eram alunas da escola neste período, embora a Marília tenha se transferido para o ensino regular comum quando cursava a antiga sexta série. Atualmente, as quatro concluíram curso superior e atuam como professoras de Libras, duas em cursos superiores (Viviane e Marília) e três (Viviane, Valéria e Kênia) atuam como professoras de Libras na mesma escola.

Com o decorrer da investigação, senti necessidade de mais informações, por exemplo, da história de um surdo que também vivenciou esta mudança, mas em outra cidade. Então convidei o Vilmar Fernando 
Carvalho, que é professor de Libras da Universidade Estadual do Centro do Paraná (UniCentro), em Guarapuava, PR. Além de minha amizade com ele, pensei que seria interessante trazer o depoimento de um homem.

Após as entrevistas, diante da dificuldade de transcrição e tradução e, também, considerando a dissertação de mestrado de Maria Manuela Bastos de Oliveira Pedrosa Branco, realizada em Portugal, que analisava narrativas escritas, eu pedi para mais uma professora universitária de Libras, a Franciele de Lima Berloffa Machado responder, por escrito, as perguntas do roteiro das entrevistas. Minha intenção foi comparar as respostas já apresentadas na língua portuguesa pelo colaborador surdo, com as que eu transcrevi e traduzi.

Por fim, considerei que se essa investigação fosse realizada por outro pesquisador, provavelmente eu seria convidada a colaborar. Decidi então "me entrevistar" por acreditar que minhas memórias poderiam contribuir também para esta "reconstrução" de como foi para os surdos vivenciarem, no espaço escolar, a transição do oralismo para o bilinguismo.

Escolhidos os colaboradores, era preciso o convite, esclarecendo os objetivos da investigação e a assinatura do Termo de Consentimento Livre e Esclarecido, o TCLE. Como a língua dos colaboradores é a Libras, meu orientador achou importante que esses instrumentos também fossem disponibilizados nessa língua. Com uma busca no Google com as palavras Termo de Consentimento em Libras, encontramos diversas possibilidades que foram consideradas para a elaboração do TCLE que realizamos em Libras. Fizemos a gravação do Convite e do TCLE. Quando do contato para a entrevista, levei o TCLE impresso para que as colaboradoras assinassem.

Estava um pouco nervosa, mas na hora da primeira entrevista a conversa foi tranquila. Quase não precisei fazer muitas perguntas. Para a segunda entrevista foi mais tranquilo ainda, porque já tinha a experiência. Todas as entrevistas depois foram tranquilas. Era sempre uma conversa de amigos. Só a segunda entrevista e a do Vilmar foram feitas na minha casa, todas as outras eu fui até a casa das pessoas.

Fiz a primeira entrevista com a colaboradora Valéria Cristina Camparotto de Souza, que foi a primeira surda a ser contratada na escola especializada que eu estudei, para auxiliar na transição do oralismo para o bilinguismo. Fiz a entrevista, gravei em vídeo e fui fazer a transcrição. Um trabalho muito difícil, porque eu via o que está sendo sinalizado pela Valéria em Libras, entendia em Libras, porque é minha primeira língua, igual a dela e 
precisava escrever na língua portuguesa. Dentro da minha cabeça precisou mudar tudo. É muito difícil fazer isso, porque a escrita usando as letras do alfabeto é artificial. Não existe a pista do som como acontece para o ouvinte. Daí, é quase igual ao ouvinte que tem a primeira língua o português, que ouve uma gravação na língua portuguesa e depois precisa transcrever em chinês. Acho que é até mais difícil, porque, mesmo a escrita do chinês sendo muito difícil, porque não é alfabética, quem está transcrevendo, escuta. No meu caso eu estou fazendo a transcrição em línguas de modalidade diferente.

Também, têm problemas, pois parece que "faltam palavras" para escrever o que o entrevistado disse de maneira fiel. Discutindo com meu orientador, pensamos que pode ser porque a Libras, embora seja uma língua do ponto de vista linguístico, ainda não tem uma tradição. Então, pode ser que existem muitas palavras que não tem sinal, isso é verdade, principalmente se são conceitos científicos, coisas só usadas no mestrado ou no doutorado. Mas, eu tive muita dificuldade mesmo. Nas transcrições que fiz eu deixei espaço só com sublinhado dos sinais que eu não encontrei as palavras, Não consegui fazer a tradução direto do sinal para palavra. Precisei fazer na narrativa, porque não precisa ser sinal para palavra, pode ser a história toda, o contexto. Eu entendo em Libras e depois conto o que entendi. É diferente de tradução literal.

Quando faltam as palavras pode ser porque o meu vocabulário seja limitado e eu não tenha condição de TRADUZIR para a Língua Portuguesa o que eu compreendi em Libras, principalmente porque preciso escrever de uma maneira que é diferente de como eu organizo o meu pensamento. Como já falei antes, para transformar o que eu escrevo, para a forma culta da língua portuguesa preciso do auxílio de uma pessoa, ouvinte e fluente em Libras. Esse foi o procedimento com todas as entrevistas, menos com a da Francieli, que ela já me entregou escrita.

Apresento vídeo em Libras de tudo que está escrito, mas vídeo simples. Quem sabe, no futuro, o surdo escreve em sistema gestográfico, como o signwriting, e seu trabalho escrito seja traduzido para a língua portuguesa. Portanto, penso que escrevendo e gravando vídeos, eu estou cumprindo meu objetivo de "dar voz aos surdos" e que esta voz também seja "escutada" pelos ouvintes.

Para finalizar, falta descrever como as entrevistas foram "analisadas". $\mathrm{Na}$ verdade, as análises aconteceram bem diferente de como eu pensava que 
iam ser. Na minha dissertação cada entrevista constituiu um capítulo e, depois, fiz um capítulo formado por reflexões sobre cinco temas que foram escolhidos a partir do que achei mais importante em todo o processo e sobre algumas coisas que os entrevistados disseram e que chamaram minha atenção. Esses temas são comentados na próxima seção.

\section{Reflexões transversais}

Quando terminei de fazer as entrevistas e fui fazer as transcrições eu já pensava como ia arrumar e apresentar todas as informações. Primeiro li alguns trabalhos e vi duas maneiras de fazer que apareciam mais vezes. Uma era separar o que os entrevistados falam em comum, que são as "categorias", e a outra era tentar montar uma história coletiva de todas as histórias contadas para mim. Achei que procurar os pontos em comum poderia ser interessante, mas muitas coisas que foram contadas só por um ou outro colaborador não seriam mostradas. Seguindo as propostas da História Oral, a dissertação mostra as narrativas completas, sem cortes, de cada colaborador. No final, como uma forma de análise, escolhi cinco temas que considerei importantes para refletir:

1. Retextualização: Língua Portuguesa/Libras: falo sobre as dificuldades que encontrei para fazer a parte teórica, para transcrever e textualizar. É sobre fazer um trabalho científico mudando de uma língua para outra.

2. O bilinguismo e a Cultura e Identidade Surda: esse tema é simples para mim hoje, depois da dissertação. Quando fiz faculdade eu estudei sobre cultura e identidade surda. Mas era teoria, parecia que não era realidade, mesmo pensando na minha experiência. Conversando com os surdos, sobre como eles viveram a mudança do oralismo para bilinguismo, eu entendi sobre cultura e identidade.

3. Implante Coclear: um novo Congresso de Milão? Esse tema surgiu da narrativa da Viviane. Ela falou muito sobre implante, do medo que ela tem de acabar a Libras. Fiquei pensando nisso e em um livro que eu li e que falava sobre isso também. Fiquei pensando: será que a Libras pode ser proibida de novo? 
4. Os ouvintes, os sons, as emoções, as transcrições: o que aprendi com a História Oral: esse tema é muito importante para mim, para a minha vida. Eu entendi melhor o que é som. Não foi com experiências ou sentindo a vibração que eu entendi o que é o som e sua função na comunicação oral. E isso aconteceu nas aulas de História Oral. Entendi o que é o som e como os ouvintes também têm dificuldades para escrever.

5. Oralizar para quem?: este tema apareceu em quase todas as conversas com os surdos. Elas contavam como as famílias obrigavam as crianças surdas aprender falar oralmente. Pensei muito e parecia egoísmo. 0 surdo precisava oralizar para ficar fácil para ouvinte entender? Porque o surdo não vai oralizar para outro surdo. Mas, depois entendi que a família e os professores só queriam ajudar. Acreditavam que era o certo.

Nesse capítulo optamos por apresentar somente trechos da quarta reflexão.

\section{Os ouvintes, os sons, as emoções, as transcrições: o que aprendi com a história oral}

Buscando entender como aconteceu a mudança do oralismo para o bilinguismo, elaborei o projeto para fazer mestrado na UFPR. Fiz a prova escrita, a entrevista e fui aprovada. O professor Carlos Vianna aceitou ser meu orientador. A primeira coisa que ele me disse foi que se eu queria saber como o surdo entendeu a mudança do oralismo para o bilinguismo, eu precisava saber o que surdo pensava, precisava conversar com os surdos. Então, para achar respostas para o que eu queria saber eu conversaria com surdos e usaria procedimentos da História Oral.

Primeira coisa que fiz foi ler um livro de História Oral, o livro: Ensaios de História Oral, de Alessandro Portelli (2010), antes mesmo de começarem as aulas do mestrado. Não entendi direito, porque contém muitas palavras difíceis. Eu li sozinha, nas férias. Não conversei com ninguém. Então não ajudou muito. O que me fez entender primeiro sobre História Oral foi dissertação da Lizmari Greca (2015), que foi também orientanda do professor Carlos e o trabalho dela foi a primeira dissertação de mestrado que eu li na 
minha vida. Eu li as narrativas dos professores (ouvintes) e achei que seria muito interessante fazer as narrativas dos surdos. Só achava um pouco confuso falar de História Oral se as conversas eram com pessoas surdas. Então, meu orientador me indicou um artigo sobre uma pesquisa com História Oral, mas quem contava a história eram os surdos. Era um texto de título: "O lugar da comunicação na aprendizagem matemática de surdos, a partir da memória de três ex-alunos", de autoria de Diogo Franco Rios e Daniel Duarte da Silveira (RIOS; SILVEIRA, 2016). Nesse texto, os autores relatam que têm muitas pesquisas sobre ensino de Matemática para surdos, mas ZERO com os surdos falando, contando suas experiências. Sempre são ouvintes. Então, eles usam História Oral e na História Oral as pessoas fazem narrativas. Nessas narrativas, as pessoas são chamadas de fontes. E os autores falavam então de fontes surdas. Interessante como não se pensa nunca nos surdos ou na existência de línguas que não são orais. A disciplina ou a metodologia podia chamar História Narrada. Resolvia o problema. Mas, voltando ao artigo, que na verdade é um capítulo de livro, achei muito importante os autores falarem em fontes surdas. Achei perfeito. Era o que eu queria fazer. Mas meu trabalho tinha duas coisas diferentes: além de ter um objeto de pesquisa distinto, os pesquisadores Diogo e Daniel, que fizeram o capítulo abordando as fontes surdas, são ouvintes.

No primeiro livro que eu li, antes das aulas, teve uma frase que achei interessante e até sublinhei no livro:

A diferença cultural entre pesquisador e narrador sujeita este último a estímulos imprevistos, força-o a explorar setores e aspectos de sua experiência que não são mencionados quando ele conta histórias ao seu círculo imediato (PORTELLI, 2010, p. 20).

O pesquisador ajuda o entrevistado a criar a narrativa. Como eu sou surda, os surdos confiariam em mim porque eles sabiam que a nossa conversa era "direta". Eles tinham certeza do que eu estava falando e tinham certeza de que eu estava entendendo "certo" o que eles falavam. Não tinha intérprete, não corria o risco de a conversa ser mudada. Essa era uma diferença importante: uma pesquisadora surda, ouvindo "fontes surdas".

Era assim que meu trabalho seria diferente. Mas precisava estudar mais.

Foi bem interessante quando meu orientador ofereceu a disciplina de História Oral no mestrado. Nesta ocasião, aprendi muita coisa; o professor 
sempre se preocupava se eu estava entendendo, sempre me incluía nas discussões e pedia que suas outras orientandas conversassem comigo, discutissem temas comigo. Também tinham os intérpretes de Libras. Nesta disciplina aprendi muito sobre como fazer pesquisa, sobre a História Oral como metodologia e como teoria. Mas tiveram duas coisas que eu aprendi com a História Oral que foram muito importantes para minha vida.

Primeira coisa: o professor mandou estudar o artigo: $O$ que faz a história oral diferente, de Alessandro Portelli (1997). Neste artigo o autor fala que fazer uma transcrição é difícil; porque quando o som (palavra oral) se transforma na palavra escrita (que é visual), muda o que a pessoa falou.

Desta forma, para ajudar os alunos entenderem isso o professor fez um exercício: ele marcou dez minutos do que ele estava explicando e todos os alunos precisavam gravar o que ele estava falando e fazer a transcrição da gravação. Depois, na outra aula, ele foi mostrando como os alunos fizeram textos diferentes. Eu não fiz essa atividade, mas observei os ouvintes fazendo. O professor pediu para que eu fizesse a comparação das transcrições feitas por duas alunas a Ana Paula e a Luciana.

Elas utilizaram os critérios de transcrição de Dino Preti (1999), mas tinham coisas que a Luciana escrevia tudo com letras maiúsculas, o que significa que o professor tinha falado forte, alto. Ana Paula indicou pausas que a Luciana não indicou. As pausas estão bem diferentes nas duas transcrições, assim como se ele falou alto ou não. Também, uma das alunas fez parágrafos bem compridos, a outra fez curto, então eu não conseguia entender como o professor tinha na verdade falado.

Eu fiquei surpresa e até assustada porque as alunas fizeram tudo diferente. Eu não sabia que ouvintes também faziam confusão sobre o que ouviam. Às vezes o surdo faz confusão nas conversas, mas quando presta atenção parece que entendem certo na Libras. Nossa, foi muito interessante porque ouvintes ESCUTAM MESMA COISA e entendem diferente.... Parecia impossível.

E isso acontece mesmo quando se tem regras. Tem código combinado. As "regras para fazer transcrição" que estudamos no livro de Dino Preti (1999). Tem regra para tudo! Dá para ouvinte perceber se a pessoa está falando brava, ou se está preocupada, ou se está pensando, se tem dúvida, se está animada só escutando a pessoa falar! Como isso é possível? Ouvinte não vê expressão facial, nada. Para mim, é muito mais fácil - eu pensava -, porque estou VENDO 
as expressões do surdo. Mas, quando eu fui comparar as transcrições que elas fizeram eu vi que os sons podem parecer diferente para cada pessoa.

Eu pensava que não ia ser muito difícil fazer a transcrição do surdo. Tudo certo se eu só transformasse a entrevista em Libras, narrativa também em Libras. Achava que não ia ter tanta confusão, porque eu não ia ter dúvidas por causa da expressão facial "das emoções" que o surdo estava colocando na conversa, se eu usasse mesma língua.

Mas, tinha uma coisa muito importante... eu queria "dar voz" para o surdo, queria que o surdo mostrasse seus sentimentos, sua emoção, contasse sua história para os ouvintes. E essa "voz" precisava ser na língua portuguesa. Assim, eu fiz uma "transcrição" que na verdade era uma "tradução", porque havia a mudança de uma língua para outra. Quando o ouvinte faz uma transcrição de outro ouvinte só muda a forma, do oral para o escrito, mas é só português. Eu traduzi da Libras para o português, depois precisei arrumar o texto de um jeito que o ouvinte poderia entender o que o surdo quer dizer.

Mas, como fazer para o surdo também entender? Como posso contar tudo isso que estudei para os surdos? Então, fiz vídeos. Meus vídeos são curtos. Não traz tudo da dissertação. São resumidos, mas fará com que os surdos entendam com clareza o que eu fiz neste trabalho e as conclusões. Não fiz vídeos das narrativas, porque as pessoas podem ver a própria entrevista em Libras.

Fico pensando: a Libras é muito importante; mas, o surdo não pode saber apenas Libras, também precisa conhecer a língua portuguesa. A escola não deve abandonar o ensino de Português, pois para o surdo poder ser livre de verdade ele precisa entender certo o que ele lê.

O surdo precisa ter informação, conhecer teoria e avançar nos estudos. Por exemplo, eu conheci a História Oral e a Teoria dos Campos Conceituais do Vergnaud. Esses livros que contém essas teorias não estão traduzidos para a Libras. Tem textos desses autores que ainda não estão nem traduzidos para o português.

Tem muita coisa para saber sobre História, Filosofia, Sociologia, Economia, etc. O surdo precisa conhecer teoria, ciência. Não pode ficar preso só no mundo da Libras. É importante lutar para ter esses conhecimentos em Libras. Na biblioteca do Instituto Nacional de Educação de Surdos (INES) já tem alguns materiais em Libras. 
É necessário produzir vídeos para criar o conhecimento em Libras; porque, se o surdo tem acesso a vídeos de Ciência, de Filosofia, de Sociologia em Libras, mesmo que não sejam de forma muito aprofundadas, mas possibilitando que tenha uma ideia antes sobre o conteúdo, fica mais fácil de entender um texto escrito quando fizer a leitura. Por isso, fiz vídeos da teoria e da metodologia da pesquisa. No capítulo da metodologia da minha dissertação eu escrevi e expliquei o que fiz no curso de mestrado para fazer a pesquisa. Expliquei tudo o que deu certo e o que não deu. Isso foi difícil de fazer, mas pode ajudar outros surdos que quiserem saber como faz pesquisa.

Quando fui estudar História Oral eu aprendi que o som faz o ouvinte perceber a emoção. Aprendi que o ouvinte também tem dificuldades para compreender e escrever textos. Isso eu aprendi vendo as dificuldades dos meus colegas. Então, o problema de escrever não é só do surdo, ouvir não é suficiente para ler e escrever. Quando eu era pequena eu via as pessoas mexendo a boca. Eu sabia que acontecia alguma coisa, só não sabia o que era. $\mathrm{O}$ surdo é visual. Surdo não escuta o som. Surdo não VÊ o som. Portanto, parece que o som não tem "poder". Não faz nada. Não existe. A História Oral mostrou que o som tem "poder".

Até lembrei de uma história que aconteceu comigo quando eu era pequena. Eu não entendia que muitas coisas têm som. Por exemplo, a tosse. Então, uma vez fui em uma apresentação e durante a apresentação ficava tudo escuro, eu era pequena e soltei um pum... Eu estava sentada atrás da minha mãe. Ela virou rápido, com cara feia, eu não entendi. Como ela descobriu o que eu fiz? Depois ela explicou. Daí eu comecei a compreender que tem coisas que faz barulho e o surdo não sabe. Eu aprendi que emoção também tem som.

Por definição, barulho é a ausência de silêncio; é um ruído ou som acústico perceptível aos ouvidos. Para a cultura surda, todavia, o barulho e o silêncio adquirem novas versões.

Na cultura surda, o barulho / som tem outros significados - é o caso da luz que acende quando a campainha toca em sua casa, a vibração do despertador colocando embaixo do travesseiro (GESSER, 2009 p. 48).

Por isso que eu considerei que compreender melhor o que é o som foi uma das coisas mais importantes que eu aprendi com a História Oral. Parece estranho. No início eu achava que tinha preconceito porque o nome é História 
ORAL. Eu queria acabar com o oral, criando "fontes surdas", mas foi com a História Oral que eu compreendi melhor o SOM.

\section{Resultados e Conclusões}

A pesquisa que eu desenvolvi teve o objetivo de registrar como aconteceu a mudança do oralismo para o bilinguismo na educação dos surdos paranaenses. Mas eu queria entender essa mudança a partir do que os surdos viveram. Eu queria dar "voz" aos surdos, ou como diz a História Oral, criar "fontes surdas". Esta preocupação de dar "voz" aos surdos ficou comigo o tempo todo. Eu também queria contribuir para criar produções científicas para os surdos. Por isso, fiz vídeos de todas as partes de minha dissertação, mas como também queria que a "voz" dos surdos fosse "ouvida" pelos ouvintes, e por exigências da pós-graduação, minha dissertação também foi escrita em português.

Essa parte de pensar em Libras e escrever na língua portuguesa ou, no caminho contrário, ler textos escritos em português e entender em Libras, posso dizer que foi uma das maiores dificuldades para mim. A História Oral procura maneiras de registrar aquilo que é falado e do jeito como a pessoa fala, então é preciso tentar registrar o "jeito da pessoa", as expressões, e até se ela respirou mais fundo, pois não é igual se a pessoa fala sem fazer essa inspiraçao. Quando a gente está fazendo a transcrição de conversa falada, até é possível tentar fazer isso, porque é de palavra para palavra, dá para escrever se a pessoa fez pausa ou se ela deu uma risada. Mas, em Libras é diferente. Existem sinais significando as palavras e a expressão facial registra emoções, sendo um dos parâmetros da Libras; a expressão facial faz parte do sinal e isso torna a transcrição mais difícil.

A forma como o surdo sinaliza também interfere na transcrição. A Valéria, por exemplo, usou Libras caseira, uma Libras que não era a culta. Quando ela foi ser instrutora, ela usava bastante sinal, porque já era casada com surdo e tinha surdo na família. Então, ela é muito rápida, usa muita gíria que não consigo traduzir no Português. As metáforas em Libras, por exemplo, são diferentes. Com a Kênia, a Viviane e a Marília, a transcrição ficou mais fácil. Nós aprendemos juntas a usar língua de sinais. Tem coisa da minha vida muito parecida com a da Valéria, Viviane e Marília. Nós temos "trauma" da escola oralista. Isso é ainda pior na escola inclusiva. A Kênia não tinha trauma com o 
oralismo. Ela fez odontologia e não queria intérprete porque oralizava bem. Mas, depois entendeu a importância da Libras e hoje ela é professora de Libras.

Eu entendo que precisamos criar as fontes surdas em Libras, porque os depoimentos seriam mais verdadeiros. $E$, também, se o material for disponibilizado só em português os surdos não vão conhecer a sua própria história. Leonardo Peluso (2015), defende que os registros em vídeo, de depoimentos em línguas de sinais, também são fontes de informação, pois podem ser arquivados e tem as mesmas características dos textos escritos. Esse autor escreve que o que está vídeogravado em língua de sinais pode ser arquivado e não muda, igual aos textos escritos, o que ele chama de "característica da permanência"; depois de realizadas, as videogravações podem ser usadas e estudadas, isto é, também possuem a "característica de objetivação" (PELUSO, 2015). São estas características, de poderem ser arquivados, de serem permanentes e poderem se constituir em objetos de estudos que tornam os vídeos documentos e fontes seguras para investigação.

Peluso (2015) ressalta também que é preciso criar materiais para os surdos poderem estudar na sua própria língua e com as tecnologias atuais, as gravações podem ser conhecidas pelos surdos. Então, penso que uma contribuição do meu trabalho para a comunidade surda é também deixá-lo em Libras, disponível no Youtube, por exemplo.

Outra coisa bem difícil para mim nesse caminho do mestrado foi compreender as regras do "mundo acadêmico". Compreender o que é uma pesquisa, compreender que primeiro preciso estudar muito, ler muitas dissertações, teses, artigos. Compreender que precisa uma metodologia de pesquisa. Para os ouvintes também é difícil; mas, para os surdos, parece ser mais ainda, porque nós surdos, de certa forma, somos "poupados" de um ensino mais rigoroso, tanto no que se refere ao volume dos conteúdos que estudamos, quanto às exigências escolares. Muitas vezes, somos "preparados" para fazer provas, com a entrega de questionários pelos professores para decorarmos. Na escola inclusiva é comum que os alunos surdos façam prova junto com os professores do atendimento educacional especializado (AEE), em dupla com algum colega, etc.; até porque os professores sabem que não estão ensinando direito ou que não estão ajudando o surdo a aprender, Então, vamos passando de ano, mas nem sempre aprendemos. 
Na faculdade é ainda mais difícil; mas, no curso de Licenciatura em Letras/Libras muitas vezes os próprios textos, como as avaliações, eram em Libras. Então, conhecer as regras desse "mundo acadêmico" e a redação e interpretação de textos na língua portuguesa foi difícil para mim. Por isso, procurei fazer bem detalhado o capítulo dos Percursos Metodológicos. Para auxiliar outros surdos que querem fazer mestrado a aprender a fazer pesquisa.

Para responder minha pergunta de pesquisa, usando a História Oral como metodologia, eu realizei cinco entrevistas, enviei um questionário que foi respondido por uma surda e fiz o meu próprio relato. O que essas narrativas me ajudaram a entender?

Primeiro, que todos nós, os surdos, que vivenciamos a transição do oralismo para o bilinguismo sentimos como se fosse uma "libertação". Por isso, escolhi meu título: Enfim posso falar! Nós passamos muito tempo da nossa vida sem conseguir nos comunicar. Sem conseguir falar o que a gente sentia. Nem mesmo com nossas famílias. Era difícil. Mas, mesmo assim, todos nós que participamos desta pesquisa conseguimos fazer um curso superior. De verdade, nós só conseguimos depois que pudemos ter a Libras dentro da sala de aula.

As narrativas dos meus amigos e minhas dificuldades para fazer este mestrado me fizeram pensar em muita coisa, que apresentei como Reflexões sobre a Dissertação e que mostram o que achei mais importante em todo esse trabalho. Para mim, as dificuldades com a língua portuguesa foram grandes. Entender o que eu lia e depois escrever o que eu entendi foi um grande desafio. Também foi difícil ver o que eu escrevia ser sempre alterado, mudado. Às vezes eu achava que as palavras que eram trocadas pela minha mãe na retextualização mudavam o que eu queria dizer. E a gente discutia. Às vezes ficava como ela tinha feito, outras vezes, ela voltava ao o que eu tinha escrito. Isto eu penso que é uma questão bem séria na produção dos trabalhos por surdos.

Lutar para os surdos poderem entregar todos os trabalhos gravados em Libras, pode ser uma saída, mas eu acho que precisamos mostrar nossas ideias também para os ouvintes. Acho que só quando os ouvintes entenderem os surdos, o que nós temos a dizer, é que a nossa inclusão vai acontecer de fato. Então, essa experiência trouxe uma dúvida: será que nas escolas inclusivas os surdos estão aprendendo a ler e escrever melhor do que quando eu estudei no oralismo? Ainda não dá para saber. 
Nossa dificuldade em escrever é grande, e não nos sentimos muito à vontade escrevendo. Quando a entrevista foi feita por escrito, mesmo com as perguntas sendo as mesmas, as respostas eram curtas; e, quando realizadas em Libras eram muito mais compridas. Acho que isso também acontece com os ouvintes, por isso é tão importante fazer mais entrevistas, conversar é melhor do que só entregar questionário.

A coisa mais importante que eu consegui compreender que aconteceu com a vida dos surdos com a mudança do oralismo para o bilinguismo, aconteceu fora da escola. Na escola foi importante, mas poder usar a língua de sinais permitiu que pudéssemos frequentar a Associação dos Surdos, conviver com surdos adultos, frequentar os pontos de encontro com nossos pares. Essa foi a grande "libertação". A gente podia ser surdo e usar a nossa língua. Então, a mudança foi muito boa para os surdos estudarem e aprenderem. Hoje, com o bilinguismo, os surdos estão fazendo faculdade, estão fazendo mestrado, doutorado. Estão fazendo pesquisas.

Outra coisa que ficou clara com essa pesquisa é que a gente ainda nem conseguiu sentir os efeitos do bilinguismo e parece que estamos vivendo uma nova mudança. Agora, do bilinguismo para o oralismo de novo. Não sei se será do mesmo jeito do oralismo que a gente conhece, por causa dos implantes. $\mathrm{O}$ problema é que sempre se acredita que uma abordagem ou uma cirurgia é o certo para TODOS os surdos. Primeiro decidiram acabar com as escolas especializadas quando mudaram para o bilinguismo. Agora, quando a criança nasce surda, já querem fazer o implante. Será que seria essa a vontade da criança? Será que no futuro, quando uma pessoa for fazer uma pesquisa para saber como os surdos que vivenciaram a volta para o (novo) oralismo sentiram, eles vão responder que foi uma "libertação"? Não sei.

O que pude concluir é que quando aconteceu a mudança do oralismo para o bilinguismo foi porque ninguém estava feliz com a educação dos surdos por meio do oralismo. Nem os professores e nem os surdos. Quando a Libras começou a ser usada em sala de aula, a Valéria contou que os professores ficaram felizes e surpresos porque viam seus alunos aprenderem. Parece que foi "libertação" para eles assim como foi para os surdos. Os professores também se sentiam "livres", porque podiam aprofundar seus assuntos. Explicar, conversar, entender o sentimento dos alunos.

E para a família? Algumas famílias ficaram "surdas" também. Os familiares dos surdos aprenderam Libras para conversar com eles, 
principalmente as mães. Outras não se dispuseram a aprender, mas as famílias dos entrevistados ficaram orgulhosas da vida dos filhos depois do bilinguismo.

Uma coisa que ainda está bem difícil é lugar para trabalhar. Trabalho com bom salário para nós parece ser quase só como professor de Libras. Isso ficou claro com a Kênia, que se formou em odontologia, mas precisou fazer outra faculdade para trabalhar e se sentir feliz. Com a Marília também; ela fez gastronomia, mas quando procurava trabalho nos restaurantes, só conseguia para lavar louça.

Falar de mudanças que aconteceram na vida não significa dizer que os surdos não perceberam que o bilinguismo mudou também a escola. Perceberam e gostaram da mudança. Uma outra coisa importante que o Vilmar contou na entrevista: se o professor entende a importância do visual para o surdo e de que pode usar a linguagem corporal para ajudar na comunicação, o aluno surdo vai compreender melhor.

Minha pesquisa mostrou que as leis ajudam bastante, que toda a mudança começou com as leis. A tecnologia também ajuda muito. É muito mais fácil ser surdo hoje com o celular e com a internet. Mas as mudanças mais importantes são as da sociedade. E essas demoram muito.

Mesmo a Libras tendo sido reconhecida como meio de comunicação legal no Brasil, os surdos têm poucas pessoas para conversar. Quase ninguém sabe Libras. Mas uma coisa é verdadeira: hoje, praticamente todo mundo sabe o que é Libras, sabe que o surdo se comunica usando as mãos. Ainda tem muita gente que acha que é mímica. Porém, estão aprendendo e começando a respeitar.

Desta forma, penso que a maior consequência da mudança do oralismo para o bilinguismo não foi educacional. Foi a social. O bilinguismo permitiu que o surdo tivesse "vida social", que construísse sua identidade, se sentisse livre e respeitado. Que compreendesse a sua cultura. Eu só cheguei a essas conclusões porque ouvi os surdos e criei fontes surdas que me mostraram como o bilinguismo fora da escola foi importante. $\mathrm{O}$ olhar dos ouvintes, dos professores ouvintes poderia mostrar como a interação na escola melhorou, como ficou mais fácil ensinar, mas a sensação de liberdade veio das fontes surdas.

Agora que terminei o trabalho eu espero que muitos surdos vejam os vídeos ou leiam meu texto e vejam "nossas vozes"; e, a partir disso, possam sentir vontade de seguir um caminho parecido com o meu, com o da Marília, 
do Vilmar, e de tantos outros surdos que já estão procurando seu mestrado e de outros surdos que já são doutores e serviram de inspiração para nós. Vamos estudar mais. Quando nós surdos estudamos, isso não é importante só para quem está estudando, mas para todos os surdos. Também vamos "falar" mais, mostrar que temos nossa opinião, mostrar os nossos desejos.

Também espero que os ouvintes "escutem a nossa voz" e enxerguem as coisas pelo nosso ponto de vista, o que a gente pensa, o que a gente quer e respeitem nossas opiniões, como no caso dos implantes. Seria muito importante se os pais conversassem com os surdos antes de decidirem "transformar" os seus filhos. Que procurem se informar sobre os resultados, sobre como os surdos implantados se sentem. Eu sei que é o sonho dos pais terem filhos iguais a eles. Eu também tinha sonho que meus filhos fossem iguais a mim. Mas, cada um pode ser MUITO FELIZ do jeito que é. E mais, minha família é ouvinte, meus filhos são ouvintes e todos têm orgulho de mim.

Eu também estou orgulhosa. Quando comecei o mestrado eu achei que não ia conseguir. Pensei em desistir algumas vezes. Agora, estou pensando no doutorado... Fazer mais pesquisas, contribuir para "escrever" a nossa própria história, constituir, eu mesma, mais fontes surdas.

\section{Referências}

BARBOSA, M.L.V.; SOUZA, E.B.. Considerações sobre o processo de retextualização para Libras de texto em português por graduandos surdos. Trabalhos em Linguística Aplicada. Campinas, n. 57.1, 2018. p. 493-521.

CUNHA JÚNIOR, E. da. O embate em torno das políticas educacionais para surdos: Federação Nacional de Educação e Integração dos surdos. Jundiaí: Paco Editorial, 2015.

GESSER, A. Libras? Que língua é essa?: crenças e preconceitos em torno da língua de sinais e da realidade surda. São Paulo: Parábola Editorial, 2009.

GOMES, M. C.. Lugares e representações do outro: a surdez como diferença. Porto: CIIE/Livpsic, 2010. 
GRECA, L. C. M. Surdez e Alfabetização Matemática: o que os profissionais e as crianças surdas da escola têm para contar. 2015. Dissertação (Mestrado em Educação em Ciências e Matemática) - Setor de Ciências Exatas, Universidade Federal do Paraná, Curitiba, 2015.

PELUSO, L. Traducción entre español escrito y lengua de señas uruguaya videograbada: un nuevo desafio. Cadernos Traduções. Florianópolis, v.5.V.especial 2. jul-dez 2015, p. 479-504.

PORTELLI, A. O que faz a história oral diferente. Projeto História. São Paulo, 14 fev.1997.

PORTELLI, A.. Ensaios de História Oral. São Paulo: Letra e Voz, 2010.

PRETI, D. Análise de textos orais. 4.ed. São Paulo: Humanitas Publicações. FFLCH/USP, 1999 (Projetos Paralelos, v.1)

RIOS, D. F.; SILVEIRA, D. D.. O Lugar da Comunicação na Aprendizagem Matemática de Surdos, a partir da Memória de três ex-alunos. In: SANTANA, C.C.; SANTANA I.P e AMARAL, R.S.. Ações colaborativas e cooperativas em educação: entre história, ensino e formação de professores. São Carlos: Pedro \& João Editores, 2016.

SILVA, J. Demonstrações em uma narrativa sinalizada em Libras. 2014.

Dissertação (Mestrado em Semiótica e Linguística Geral) - Programa de PósGraduação em Semiótica e Linguística Geral, Universidade de São Paulo, 2014.

SILVA, D. N. H.; ABREU, F.S.D.. Narrativas de jovens surdos sobre seus processos de escolarização no Distrito Federal. Linhas Críticas. Brasília: Universidade de Brasília. v. 20, n. 42, maio/ago., 2014, p. 325-344.

SKLIAR, C.. (Org.). A surdez: um olhar sobre as diferenças. Porto Alegre: Mediação, 1998. 
SOUZA, R.,M.; PEREZ, V. E. M.; ROSA, A. S.; NUNES, H. A..; Narrando em sinais: se vendo e se fazendo surdo. In: III CONFERÊNCIA DE PESQUISA SOCIOCULTURAL, 2000,. Campinas, Anais..., Campinas, UNICAMP, maio 2000. 